\section{Deltaschlaf-induzierendes Peptid}

Helga Peter ${ }^{1}$ und Thomas Penzel ${ }^{2}$

${ }^{1}$ Marburg, Deutschland

${ }^{2}$ Interdisziplinäres Schlafmedizinisches Zentrum, Charité -

Universitätsmedizin Berlin, Berlin, Deutschland

\section{Synonyme}

DSIP

\section{Englischer Begriff}

delta sleep inducing peptide

\section{Definition}

Infusion von DSIP kann bei Kaninchen Tiefschlaf auslösen. Für die Anwendung bei Patienten mit Insomnie liegen widersprüchliche Ergebnisse vor. 